\title{
The Phycotoxin Domoic Acid as a Potential Factor for Oxidative Alterations Enhanced by Climate Change
}

\author{
Joaquin Cabrera ${ }^{1,2}$, Paula Mariela González ${ }^{1,2}$ and Susana Puntarulo ${ }^{1,2 *}$ \\ ${ }^{1}$ Universidad de Buenos Aires, Facultad de Farmacia y Bioquímica, Fisicoquímica, Buenos Aires, Argentina, ${ }^{2}$ Instituto de \\ Bioquímica y Medicina Molecular (IBIMOL), Consejo Nacional de Investigaciones Científicas y Técnicas \\ (CONICET)-Universidad de Buenos Aires, Buenos Aires, Argentina
}

Keywords: domoic acid, harmful marine toxins, oxidative stress, photosynthetic organisms, climate change

\section{INTRODUCTION}

The climate change affects water quality and sustainable development; therefore, security of the aquatic communities is altered (World Meteorological Organization, 2020). However, data on water resources are patchy and incomplete. Exceptional global heat, retreating ice, and high sea

OPEN ACCESS

Edited by:

Benoit Schoefs,

Le Mans Université, France

Reviewed by:

John P. Bucci,

University of New Hampshire, United States Julio Turrens,

University of South Alabama,

United States

*Correspondence:

Susana Puntarulo susanap@ffyb.uba.ar

Specialty section:

This article was submitted to Marine and Freshwater Plants,

a section of the journal

Frontiers in Plant Science

Received: 28 June 2020 Accepted: 18 September 2020

Published: 30 October 2020

Citation:

Cabrera J, González PM and Puntarulo S (2020) The Phycotoxin Domoic Acid as a Potential Factor for Oxidative Alterations Enhanced by Climate Change.

Front. Plant Sci. 11:576971. doi: 10.3389/fpls.2020.576971 level records driven by greenhouse gases from human activities were described over the last decade. Average temperatures for the 5-year (2015-2019) and 10-year (2010-2019) periods are almost certain to be the highest on record. The scenario is the same in each point of the planet because the heating induced by human activities is affecting the scale and intensity of extreme meteorological phenomena. Levels of heat-trapping greenhouse gases in the atmosphere have reached another high new record in 2018 [37,000 tons of carbon dioxide $\left(\mathrm{CO}_{2}\right)$ ], and threat to ocean life is huge because more than $90 \%$ of excess heat caused by global change ends up affecting water and aquatic life. Over the last decades, oceans have become more acid ( $0.1 \mathrm{pH}$ unit) because the increase in dissolved $\mathrm{CO}_{2}$ causes this effect (IPCC Intergovernmental Panel on Climate Change, 2007).

Phytoplankton productivity, specifically that of diatoms with a relatively large cell size, is limited by iron (Fe) availability in the high-nutrient, low-chlorophyll (HNLC) region of the ocean (de Baar et al., 2005). Fe availability will change with the increasing contribution of ferrous to ferric $\mathrm{Fe}$ (Millero et al., 2009) and the conditional stability constant of Fe-ligand complex (Shi et al., 2010) in response to the increase in the acidity of seawater. Other human perturbations, such as land use and $\mathrm{SO}_{2}$ and $\mathrm{NO}_{\mathrm{x}}$ emissions, will also alter the Fe distribution and bioavailability in the open oceans (Mahowald et al., 2009). The interactive effects of the ocean acidification and the Fe availability are expected to play crucial roles in the biogeochemical cycling of nutrients in the HNLC regions. The elemental composition of unialgal culture of Pseudo-nitzschia pseudodelicatissima changed in response to alterations in both $\mathrm{CO}_{2}$ levels and bioavailable dissolved inorganic Fe concentrations (Sugie and Yoshimura, 2013). Sugie et al. (2013) reported that high $\mathrm{CO}_{2}$ affects nutrient dynamics in Fe-limited phytoplankton communities.

In marine environments, some microalgae (diatoms, dinophyceae, rhodophyte, dinoflagellates), ciliates, and cyanobacteria species synthetize toxins (Reguera, 2002) that diffuse out of the organisms and reach other aquatic systems directly from the water or through the trophic transfer. Continued acidification of the ocean inhibits the growth of phytoplankton species that have shells of calcium carbonate, which dissolve in acidic conditions, and the growth of organisms without calcium carbonate shells is favored (Moore et al., 2008). During harmful algal blooms (HABs), bloom-forming diatom species tend to be more flexible in the use of different carbon sources, and these abilities may provide a competitive advantage, especially under changing conditions as they occur during a bloom. The ocean acidification during blooms favored organisms that fix $\mathrm{CO}_{2}$ such 
as some diatoms (Hansen, 2002). It has been reported that Pseudo-nitszchia australis (Wingert, 2017), P. pseudodelicatissima (Sugie and Yoshimura, 2013), and Pseudo-nitszchia subcurvata increase their growth rate under these conditions. Even more, Pseudo-nitzschia multiseries increase the production of the biotoxin domoic acid (DA) (Trimborn et al., 2008). Degraded water quality from nutrient pollution, physical, biological, and other chemical factors contribute to the growth and persistence of many HABs (Cabrera et al., 2019a). The most severe consequences of HABs include effects on fish, bird, and mammal mortalities, by respiratory or digestive tract problems, memory loss, seizures, lesions, and skin irritation (Sellner et al., 2003). Fluctuating seasonally, temperature, oxygen $\left(\mathrm{O}_{2}\right)$ consumption, availability of food, endogenous rhythms, and HABs are among the important potential stressors studied for aquatic organisms.

The community composition and toxigenicity of the diatom Pseudo-nitzschia in the open South Atlantic Ocean were characterized during the austral spring of 2007 by Guannel et al. (2015). Multiple morphological types of Pseudo-nitzschia were detected in coastal and in open-ocean waters. The toxin produced by Pseudo-nitzschia, DA, was present in at least 10 species in the South Atlantic (Gayoso, 2001; Reguera, 2002). Even though Pseudo-nitzschia sp. blooms occur in different environmental conditions, Marchetti et al. (2004) and Wells et al., 2005) showed a positive correlation between these blooming events and high levels of $\mathrm{Fe}(\mathrm{III})$ and $\mathrm{NO}_{3}^{-}$, and low levels of $\mathrm{PO}_{4}^{3-}$ and $\mathrm{SiO}_{4}^{4-}$. Even more, differences in temperature, salinity, $\mathrm{pH}$, high irradiance, and long-term photoperiod can affect the formation of Pseudo-nitzschia blooms (Lelong et al., 2012). Woods (2016) suggested a possible photo-oxidative stress regulation on DA's higher production under high irradiance. Cellular stress produced by these conditions may favor the production of toxins during $\mathrm{HAB}$ events. The main objective of this opinion article is to briefly report the toxicological implications of the harmful marine phycotoxin DA and its intrinsic properties. Special focus will be made on the reported oxidative stress status in marine algae in relation to the exposure to DA. Moreover, because Fe presence is known to be implicated in oxidative stress generation, and its occurrence seems to be a fundamental factor in the production of DA, the oxidative effects of the biotoxin will be discussed in relation to its capacity to bind Fe.

\section{CHEMICAL, BIOLOGICAL, AND PRODUCTION FEATURES OF DA}

DA is a tricarboxylic amino acid belonging to the category of cainoids (Wright and Quilliam, 1995). The main chemical features of DA $\left(\mathrm{C}_{15} \mathrm{H}_{21} \mathrm{NO}_{6}\right)$ are as follows: average mass of $311.330 \mathrm{Da}$ and percent composition of $57.87 \% \mathrm{C}, 6.80 \% \mathrm{H}$, $4.50 \% \mathrm{~N}$, and $30.83 \% \mathrm{O}$ (Merck online index). Pure DA appears as colorless crystal needles. It is heat-stable and soluble in water, dilute mineral acids, and alkali solutions. It is slightly soluble in methanol and ethanol and insoluble in petroleum ether and benzene (Jenkins, 1996).
Even though DA was identified in 1975 as being produced from the Mediterranean macroalgae Alsidium corallinum, it was first isolated from the red alga Chondria armata. Its extracts have been used as an ascaricidal medication (Daigo, 1959) and as insecticide (Iverson and Truelove, 1994). DA was later found in either microalgae species (diatoms) or macroalgae species (red algae) (Ravn, 1995). This biotoxin was identified as a public health risk toxin after an incident occurred in 1987 on Prince Edward Island, Canada (Wright and Quilliam, 1995). It is recognized that mussels contaminated with high levels of DA from algae, when are consumed by humans, produce a severe disorder known as amnesic shellfish poisoning (ASP), which could even lead to the patient death (Pulido, 2008). However, no systematic information is known up to now about DA actions in photosynthetic organisms.

DA is an excitatory amino acid containing the structure of glutamic acid and resembles kainic acid (Todd, 1989). DA binds at the same receptor site in the central nervous system than kainic and glutamic acid (Mok et al., 2009), and its coexisting natural chemical analogs act as a potent excitatory neurotransmitter. Transmembrane absorption and biological barriers interaction with DA were reported. According to data provided by Preston and Hynie (1991), the blood-brain barrier greatly limits the amount of toxin that enters the brain in vertebrates. Kimura et al. (2011) studied the transcellular transport and intestinal absorption mechanism of DA through intestinal Caco-2 cellular monolayers. Their results suggested that the apical and basolateral transport of DA through these cells is mediated by anion transporters.

The biosynthesis pathway of the DA is not fully elucidated, but it is known that large amounts of ATP are required for its production (Pan et al., 1998; Thessen, 2007). Recently, Brunson et al. (2018) established a biosynthesis model by finding a cluster of genes related to recombinant DA biosynthetic enzymes and linked their mechanisms to the construction of a pyrrolidine skeleton. Moreover, Sobrinho et al. (2017) determined that DA concentrations of $P$. multiseries significantly increased under high Fe concentration, suggesting that Fe is required for the toxin synthesis. Extracellular DA in water undergoes photodegradation or biodegradation and does not accumulate in the water column (Bejarano et al., 2008; Zabaglo et al., 2016). However, the adsorption of $\mathrm{AD}$ in the sediment can have a long-term impact on the trophic web due to its transfer through benthic organisms (Burns and Ferry, 2007; Zabaglo et al., 2016).

\section{GENERAL CHARACTERISTICS OF DA ON THE OXIDATIVE METABOLISM}

\section{Algal Ecology}

Even though physiological and ecological roles for some marine toxins produced during HABs were postulated, the matter is not fully understood. Ding et al. (2007) suggested that responses of marine plants to adverse environmental conditions involve excess production of reactive $\mathrm{O}_{2}$ species (ROS). A cellular signaling, generated by the effects of the phycotoxins, results in a free radical cascade and activation of enzymatic 
processes. Consequently, an extensive damage of cell structures and ultimate cell death has been described (Aarts and Tymianski, 2004). Phytoplankton is responsible for the $50 \%$ of global primary production in the ocean, sustaining the pelagic food chains in the aquatic ecosystems (Roig, 2000), and for the substantial sink for $\mathrm{CO}_{2}$ in marine ecosystems. Then, if these organisms are adversely affected, the surrounding ecosystem may also feel the effects, either directly or indirectly, from the lack of a food source (Wang and Zheng, 2008).

\section{Hypotheses of DA Actions}

Several hypotheses were presented to explain the potential roles for DA in the toxin productive algae: (1) Doucette et al. (2008) and Jackson et al. (1992) postulated that it could serve as an osmolyte under conditions of increasing salinity; (2) Tammilehto et al. (2015) suggested that it may act as a long sighted protection of the algae against the action of consumers such as copepods; (3) Trick et al. (2010) and Rue and Bruland (2001) proposed that DA could be a binding ligand for trace nutrients such as transition metals; (4) Xu et al. (2015) suggested that it may have allelopathic effects in other members of the phytoplankton community, stimulating changes in the dynamics and composition of this algae. Besides the possible combination of several of these actions, the DA effect on the rest of the photosynthetic community is an interesting point to investigate because its effect on non-toxinproductive aquatic organisms is not clear.

\section{New Methods of Inquiry}

Allelopathic interactions between plants and other photosynthetic organisms showed both positive (hormesis) and negative (oxidative stress) effects, through the release of chemicals into the environment. These toxic effects include inhibition of growth of various organs and delay or restriction of seed germination (Abrahim et al., 2000). Oxidative stress could participate in the allelopathic response due to overproduction of ROS and alterations in the cellular antioxidant system (Abrahim et al., 2003; Bai et al., 2009). Pseudo-nitzschia cells can have allelopathic effects in sympathetic species (Granéli and Hansen, 2006). Lundholm et al. (2005) examined the potential allelopathic effect of pure DA additions to cultures of different phytoplankton species. In this study, the tested species were selected in order to represent different algal classes that occur in natural environments together with $P$. multiseries. The lack of allelopathic effects of the DA-producing marine diatom was reported under those experimental conditions. However, recent studies (Xu et al., 2015) have shown possible allelopathic effects in Fe-enrichment conditions in laboratory cultures (Prince et al., 2013; Sobrinho et al., 2017). Even more, Bates et al. (2018) suggested that DA could indirectly improve the competitive ability of Pseudo-nitzschia sp. on a phytoplankton community, and Fe is likely to be involved in this effect. Olson and Lessard (2010) argued that high concentrations of DA located within the diffusion zone of a cell can also affect microzooplankton grazing.

\section{Oxidative Effects Produced by DA}

The generation of oxidative stress due to the exposure to DA has been reported in a large number of animal species, such as bivalves, fish, and aquatic and terrestrial mammals, as a secondary effect of its neurotoxicity (Zabaglo et al., 2016). Increased ROS formation was also observed in the nematode Caenorhabditis elegans when it was exposed to DA (Tian and Zhang, 2019). Moreover, an antioxidant treatment suppressed the toxic effects of the DA on the locomotion behavior of the nematodes, suggesting that oxidative stress is possibly involved in the mechanism of DA toxicity. In photosynthetic organism, the oxidative condition of the pennate diatom Phaeodactilum tricornutum, a non-toxin-producing microalgae, was characterized during the exposure to DA under laboratory conditions. The reported evidence suggested that when $P$. tricornutum was exposed to DA, (a) the reactive species generation rate was increased in the intracellular environment (Cabrera et al., 2019a), and (b) the reactive species were released to the extracellular medium (Cabrera et al., 2019b,c). Cabrera et al. (2019a) reported DA effects in terms of oxidative status of $P$. tricornutum during the exponential (EXP) phase, incubated in the presence of $64 \mu \mathrm{M}$ DA. The generation of active species was measured following the oxidation rate of $2^{\prime}, 7^{\prime}$ dichlorofluorescein diacetate (DCFH-DA). The linear increase in the production of reactive species from both control and exposed algae homogenates was significantly higher in cells incubated in the presence of DA, as compared to control ones. Also, the reaction rate was measured in the presence of scavengers, suggesting a similar contribution of several active species $\left(\mathrm{H}_{2} \mathrm{O}_{2}, \mathrm{Fe}\right.$, and $\left.\mathrm{O}_{2}^{-}\right)$. To study the effects on the extracellular environment, $P$. tricornutum cells were exposed to DA, washed with buffer, and incubated with DCFH-DA. After isolation of the cells by centrifugation, the release of reactive species to the supernatant was assessed by the oxidation rate of DCFH-DA using either control or cells previously exposed to DA. An increase by three-fold was reported in treated cells in the EXP phase of development, as compared to control ones. This oxidation rate was decreased in the presence of superoxide dismutase, catalase, dimethyl sulfoxide, desferroxamine, and glutathione (Cabrera et al., 2019b,c). Similar profiles were observed in either LAG or stationary (ST) phases of growth of the cells previously incubated with DA. Moreover, many studies reported dissolved DA in seawater (de la Iglesia et al., 2008; Mafra et al., 2009; Vera-Avila et al., 2011; Wang et al., 2012; Godinho et al., 2018) showed that during blooms of $P$. multiseries dissolved DA could be detected in the culture medium. These results could suggest that waterborne exposure of marine organism should be considered in a macroscale situation such as algal blooms. Taking into consideration this possible scenario, the enhanced production of DA during HABs could increase the release of DA to the aquatic environment, and the effects on oxidative stress conditions on other members of the community could be affected.

\section{DISCUSSION}

Alterations of the nutrient influx in marine water due to climate change could modify HAB frequency and magnitude, increasing its impacts. The diagram shown in Figure 1 briefly describes 


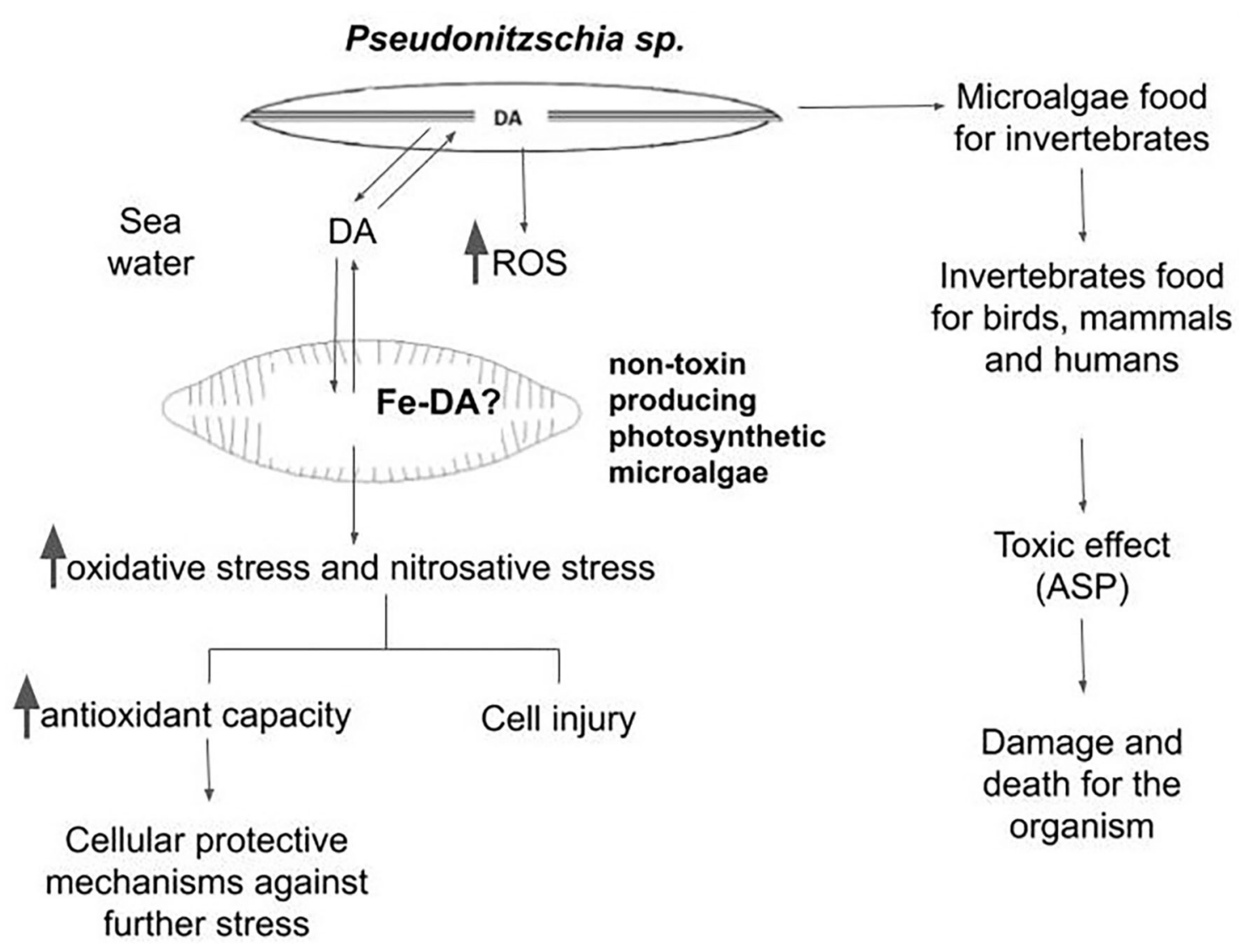

FIGURE 1 | Schematic diagram showing the possible interactions between the phycotoxin-producing microalgae and the web community in aquatic environments.

a possible scenario in the aquatic environment. On the one hand, when Pseudo-nitzschia cells produce DA in considerable amounts, the toxin gets into the food chain. When this occurs, DA could lead to the death of certain consumers. In humans, the poisoning was characterized by a constellation of clinical symptoms and signs, involving multiple organ systems, including the gastrointestinal tract, the central nervous system, and the cardiovascular system. Among the most prominent features described was memory impairment, which led to ASP, which could be even lethal.

On the other hand, DA production starts in late EXP and ST phase of the Pseudo-nitzschia growth cycle (Lelong et al., 2012). In the late ST phase, cells are physiologically impaired by injury in the structure of the wall and in the membrane (Pan et al., 1996). Therefore, DA tends to be released into the culture medium, along with ROS generated by the cells (as shown by Cabrera et al., $2019 b, c)$. Because of the short life span of ROS, this increased production could not be very effective in damaging other organisms in the aquatic community. However, the release of DA could allopathically affect (protect or injure) other species of non-toxin-producing photosynthetic microalgae. Using a highly sensitive adsorptive cathodic stripping voltammetric technique, Rue and Bruland (2001) showed that DA forms Fe chelates with a conditional stability constant of $\mathrm{K}_{\text {condFeDA,Fe(III) }}=10^{8.7 \pm 0.5} \mathrm{M}^{-1}$. The degree to which the DA acts as a trace metal chelator reveals that it has the potential to modify the availability of these metals in the seawater. Thus, the physiological role of DA for toxigenic Pseudo-nitzschia species may be tied closely to the acquisition of Fe in coastal waters. Among several other postulations, the formation of a Fe-DA complex could be a very attractive hypothesis to explain the increased generation of ROS both in producing and non-phycotoxin-generating species. Chemical aspects of the Fe chelators, such as Fe affinity, Fe selectivity, molecular weight, and lipophilicity, in addition to stability and redox properties of the resultant Fe complex, drastically change the ability of the Fe complex to catalyze radical generation. The presence of a catalytically active Fe-DA complex could favor lipid peroxidation and radical generation in a significative amount, by affecting the composition of the labile Fe content within the cells. This is a novel point of view that should be further explored. The capacity of the antioxidant defense in each species will be the main factor to determine the hormetic (beneficial) or the damaging effect of the triggering of the burst of oxidative species.

However, other alternatives could be considered under changing environmental conditions that can modify DAdependent active species generation in aquatic organisms. 
Hypoxia is a common condition in aquatic environments, and exposure to hypoxia followed by reoxygenation is often believed to induce oxidative stress and activation of relevant signaling molecules such as the hypoxia-inducible factor $1 \alpha$. This transcription factor is a potent coordinator of acclimation processes in various stress conditions. Eutrophication and extensive algal blooms caused by anthropogenic activity (input of nutrients, fertilizers, and human waste) deplete the ocean and lake bottoms of $\mathrm{O}_{2}$, i.e., make them hypoxic. In the seas, the large hypoxic areas are also known as hypoxic dead zones, and they are expanding quickly (Conley et al., 2009). Hypoxic bottoms release phosphorus from the aquatic sediments, which feed the algae even further. Hypoxia has an acute effect on the benthic fauna, and if the hypoxic environments are allowed to expand further, the whole ecosystem will be disturbed (Conley et al., 2009; Conley, 2012). Recently, Borowiec and Scott (2020) reported that hypoxia acclimation of killifish leads to adjustments in ROS homeostasis and oxidative status that do not reflect oxidative stress, but may instead be part of the suite of responses used to cope with chronic hypoxia. Thus, in situ studies could show the alterations due to other transitory changes in the environment that may occur during the HABs. Overall, the specific cellular

\section{REFERENCES}

Aarts, M. M., and Tymianski, M. (2004). Molecular mechanisms underlying specificity of excitotoxic signaling in neurons. Curr. Mol. Med. 4, 137-147. doi: 10.2174/1566524043479202

Abrahim, D., Braguini, W. L., Kelmer-Bracht, A. M., and Ishii-Iwamoto, E. L. (2000). Effects of four monoterpenes on germination, primary root growth, and mitochondrial respiration of maize. J. Chem. Ecol. 26, 611-624. doi: 10.1023/A:1005467903297

Abrahim, D., Francischini, A. C., Pergo, E. M., Kelmer-Bracht, A. M., and Ishii-Iwamoto, E. L. (2003). Effects of $\alpha$-pinene on the mitochondrial respiration of maize seedlings. Plant Physiol. Biochem. 41, 985-991. doi: 10.1016/j.plaphy.2003.07.003

Bai, R., Zhao, X., Ma, F., and Li, C. (2009). Identification and bioassay of allelopathic substances from the root exudates of Mains prunifolia. Allelop. J. 23, 477-484. Available online at: https://www.researchgate.net/publication/ 286360575_Identification_and_bioassay_of_allelopathic_substances_from_ the_root_exudates_of_Malus_prunifolia

Bates, S., Hubbard, K., Lundholm, N., Montresor, M., and Leaw, C. P. (2018). Pseudo-nitzschia, Nitzschia, and domoic acid: new research since 2011. Harm. Algae 79, 3-43. doi: 10.1016/j.hal.2018.06.001

Bejarano, A. C., Van Dola, F. M., Gulland, F. M., Rowles, T. K., and Schwacke, L. H. (2008). Production and toxicity of the marine biotoxin domoic acid and its effects on wildlife: a review. Hum. Ecol. Risk Assess. 14, 544-567. doi: 10.1080/10807030802074220

Borowiec, B. G., and Scott, G. R. (2020). Hypoxia acclimation alters reactive oxygen species homeostasis and oxidative status in estuarine killifish (Fundulus heteroclitus). J. Exp. Biol. 223:jeb222877. doi: 10.1242/jeb.222877

Brunson, J. K., McKinnie, S. M. K., Chekan, J. R., McCrow, J. P., Miles, Z. D., Bertrand, E. M., et al. (2018). Biosynthesis of the neurotoxin domoic acid in a bloom-forming diatom. Science 361, 1356-1358. doi: 10.1126/science.aau0382

Burns, J. M., and Ferry, J. L. (2007). Adsorption of domoic acid to marine sediments and clays. J. Environ. Monit. 9, 1373-1377. doi: 10.1039/b713101a

Cabrera, J., González, P. M., and Puntarulo, S. (2019a). Oxidative effects of the harmful algal blooms on primary organisms of the food web. Biocell 43, 41-50. doi: 10.32604/biocell.2019.06163

Cabrera, J., González, P. M., and Puntarulo, S. (2019b). Alteraciones Oxidativas Dependientes de la Presencia de Ácido Domoico en la Microalga Phaeodactylum response to the increased oxidative stress triggered by DA will be one of the important factors to allow survival of each organism that contribute to determine how the composition of the community will be affected by an increasing magnitude of the $\mathrm{HAB}$ season produced by the climate global change.

\section{AUTHOR CONTRIBUTIONS}

JC contributed to the bibliographic search and in the manuscript writing. PG contributed to the manuscript writing. SP participated in the designing of the original opinion idea and in the manuscript writing. All authors contributed to the article and approved the submitted version.

\section{FUNDING}

This study was supported by grants from the University of Buenos Aires (UBACyT 20020170100199BA) and National Council for Science and Technology (CONICET PIP 11220170100539CO). PG and SP are career investigators from CONICET and JC is a fellow from CONICET. tricornutum. Ph.D. dissertation. XII Simposio de Ficología, Sociedad Argentina de Ficología. CABA.

Cabrera, J., González, P. M., and Puntarulo, S. (2019c). Efecto del ácido domoico sobre la respuesta oxidativa de Phaeodactylum tricornutum. Abstract retrieved from XVIII Congreso Latinoamericano de Ciencias del Mar, Asociación Latinoamericana de Investigadores en Ciencias del Mar, November 4 - 8, Mar del Plata, 396.

Conley, D. J. (2012). Save the Baltic Sea. Nature 486, 463-464. doi: 10.1038/486463a Conley, D. J., Bjorck, S., Bonsdorff, E., Carstensen, J., Destouni, G., Gustafsson, B. G., et al. (2009). Hypoxia-related processes in the Baltic Sea. Environ. Sci. Technol. 43, 3412-3420. doi: 10.1021/es802762a

Daigo, K. (1959). Studies on the constituents of Chondriaarmata. III. Constitution of domoic acid. J. Pharmacol. Soc. 79, 356-360. doi: 10.1248/yakushi1947.79.3_356

de Baar, H. J. W., Boyd, P. W., Coale, K. H., Landry, M. R., Tsuda, A., Assmy, P., et al. (2005). Synthesis of iron fertilization experiments: from the iron age in the age of enlightenment. J. Geophys. Res. 110, 1-24. doi: 10.1029/2004JC002601

de la Iglesia, P., Gimenez, G., and Diogene, J. (2008). Determination of dissolved domoic acid in seawater with reversed-phase extraction disks and rapid resolution liquid chromatography tandem mass spectrometry with head-column trapping. J. Chromatogr. A 1215, 116-124. doi: 10.1016/j.chroma.2008.10.123

Ding, J., Sun, Y., Xiao,. C. L., Shi, K., Zhou, Y. H., and Yu, J. Q. (2007). Physiological basis of different allelopathic reactions of cucumber and fig leaf gourd plants to cinnamic acid. J. Exp. Bot. 58, 3765-3773. doi: 10.1093/jxb/erm227

Doucette, G. J., King, K. L., Thessen, A. E., and Dortch, Q. (2008). The effect of salinity on domoic acid production by the diatom Pseudo-nitzschia multiseries. Nov. Hed. 133, 31-46. Available online at: https://www.academia. edu/211278/The_effect_of_salinity_on_domoic_acid_production_by_the_ diatom_Pseudo_nitzschia_multiseries

Gayoso, A. M. (2001). Observations on Alexandrium tamarense (Lebour) balech and other dinoflagellate populations in Golfo Nuevo, Patagonia (Argentina). J. Plank. Res. 23, 463-468. doi: 10.1093/plankt/23.5.463

Godinho, L., Silva, A., Castelo Branco, M. A., Marques, A., and Reis Costa, P. (2018). Evaluation of intracellular and extracellular domoic acid content in Pseudo-nitzschia multiseries cell cultures under different light regimes. Toxicon 155, 27-31. doi: 10.1016/j.toxicon.2018. 10.003 
Granéli, E., and Hansen, P. J. (2006). “Allelopathy in harmful algae: A mechanism to compete for resources?", in Ecology of Harmful Algae. Ecological Studies (Analysis and Synthesis), eds E. Granéli, and J. T. Turner (Berlin: Springer) 189-201. doi: 10.1007/978-3-540-32210-8

Guannel, M. L., Haring, D., Twiner, M. J., Wang, Z., Noble, A. E., Lee, P. A., et al. (2015). Toxigenicity and biogeography of the diatom Pseudo-nitzschia across distinct environmental regimes in the South Atlantic Ocean. Mar. Ecol. Prog. Ser. 526, 67-87. doi: 10.3354/meps 11027

Hansen, P. J. (2002). Effect of high $\mathrm{pH}$ on the growth and survival of marine phytoplankton: implications for species succession. Aquat. Microb. Ecol. 28, 279-288. doi: 10.3354/ame028279

IPCC Intergovernmental Panel on Climate Change (2007). "Summary for policymakers," in Climate Change 2007: Impacts, Adaptation and Vulnerability Contribution of Working Group II to the Fourth Assessment Report of the Intergovernmental Panel on Climate Change. eds. M. L. Parry, O. F. Canziani, J. P. Palutikof, P. J. van der Linden, C. E. Hanson (Cambridge: Cambridge University Press), 7-22.

Iverson, F., and Truelove, J. (1994). Toxicology and seafood toxins: domoic acid. Nat. Toxins 2, 334-339. doi: 10.1002/nt.2620020514

Jackson, A. E., Ayer, S. W., and Laycock, M. V. (1992). The effect of salinity on growth and amino acid composition in the marine diatom Nitzschia pungens. Canad. J. Bot. 70, 2198-2201. doi: 10.1139/b92-272

Jenkins, J. (1996). Domoic acid in Oregon Seafood Harvest. ExToxNet. Avaiable online at: http://ace.orst.edu/cgi-bin/mfs/01/tics/domoic.asc? (accessed March $5,1996)$.

Kimura, O., Kota, Y., Hamaue, N., Haraguchi, K., and Endo, T. (2011). Transcellular transport of domoic acid across intestinal Caco-2 cell monolayers. F. Chem. Tox. 49, 2167-2171. doi: 10.1016/j.fct.2011.06.001

Lelong, A., Hégaret, H., Soudant, P., and Bates, S. S. (2012). Pseudonitzschia (Bacillariophyceae) species, domoic acid and amnesic shellfish poisoning: revisiting previous paradigms. Phycologia 51, 168-216. doi: 10.2216/ $11-37.1$

Lundholm, N., Hansen, P. J., and Kotaki, Y. (2005). Lack of allelopathic effects of the domoic acid-producing marine diatom Pseudo-nitzschia multiseries. Mar. Ecol. Prog. Ser. 288, 21-33. doi: 10.3354/meps 288021

Mafra, L. L. Jr., Leger, C., Bates, S. S., and Quilliam, M. A. (2009). Analysis of trace levels of domoic acid in seawater and plankton by liquid chromatography without derivatization, using UV or mass spectrometry detection. J. Chromatogr. A 1216, 6003-6011. doi: 10.1016/j.chroma.2009.06.050

Mahowald, N. M., Engelstaedter, S., Luo, C., Sealy, A., Artaxo, P., BenitezNelson, C., et al. (2009). Atmospheric iron deposition: global distribution, variability, and human perturbations. Annu. Rev. Mar. Sci. 1, 245-278. doi: 10.1146/annurev.marine.010908.163727

Marchetti, A., Trainer, V. L., and Harrison, P. J. (2004). Environmental conditions and phytoplankton dynamics associated with Pseudo-nitzschia abundance and domoic acid in the Juan de Fuca. Mar. Ecol. Prog. Ser. 281, 1-12. doi: $10.3354 /$ meps 281001

Millero, F. J., Woosley, R., DiTrolio, B., and Waters, J. (2009). Effect of ocean acidification on the speciation of metals in seawater. Ocean 22, 72-85. doi: 10.5670/oceanog.2009.98

Mok, J., Lee, T.-S., Oh, E.-G., Son, K.-T., Hwang, H.-J., and Kim, J. H. (2009). Stability of domoic acid at different temperature, $\mathrm{pH}$ and light. K. J. Fish. Aq. Sci. 42, 8-14. doi: 10.5657/kfas.2009.42.1.008

Moore, S. K., Trainer, V. L., Mantua, N. J., Parker, M. S., Laws, E. A., Backer, L. C., et al. (2008). Impacts of climate variability and future climate change on harmful algal blooms and human health. Environ. Health 7:S4. doi: 10.1186/1476-069X-7-S2-S4

Olson, M. B., and Lessard, E. J. (2010). The influence of the Pseudo-nitzschia toxin, domoic acid, on microzooplankton grazing and growth: a field and laboratory assessment. Harm. Alg. 9, 540-547. doi: 10.1016/j.hal.2010.04.002

Pan, Y., Bates, S. S., and Cembella, A. D. (1998). Environmental stress and domoic acid production by Pseudo-nitzschia: a physiological perspective. Nat. Toxins 6, 127-135. doi: 10.1002/(SICI)1522-7189(199805/08)6:3/4<127::AID-NT9>3. $0 . \mathrm{CO} ; 2-2$

Pan, Y. L., Subba Rao, D. V., and Mann, K. H. (1996). Changes in domoic acid production and cellular chemical composition of the toxigenic diatom Pseudo-nitzschia multiseries under phosphate limitation. J. Phycol. 32, 371-381. doi: 10.1111/j.0022-3646.1996.00371.x
Preston, E., and Hynie, I. (1991). Transfer constants for blood-brain barrier permeation of the neuroexcitatory shellfish toxin, domoic acid. Canad. J. Neurol. Sci. 18, 39-44. doi: 10.1017/S0317167100031279

Prince, E. K., Irmer, F., and Pohnert, G. (2013). Domoic acid improves the competitive ability of Pseudo-nitzschia delicatissima against the diatom Skeletonema marinoi. Mar. Drugs 11, 2398-2412. doi: 10.3390/md11072398

Pulido, O. M. (2008). Domoic acid toxicologic pathology: a review. Mar. Drugs 6, 180-219. doi: $10.3390 / \mathrm{md} 6020180$

Ravn, H. (1995). "HAB Publication Series Volume 1. Amnesic Shellfish Poisoning (ASP)," in Intergovernmental Oceanographic Commission Manuals and Guides No 31 eds. (Paris: UNESCO), 1-15.

Reguera, B. (2002). "Establecimiento de un programa de seguimiento de microalgas tóxicas," in Floraciones Algales Nocivas del Cono Sur Americano, Instituto Español de Oceanografía, eds E. A. Sar, M. A. Ferraro, B. Reguera (Madrid: Instituto Español de Oceanografía), 19-54.

Roig, X. (2000). Aquatic Photosynthesis, eds P. G. Falkowski and J. A. Raven. Madrid: Springer-Verlag.

Rue, E., and Bruland, K. (2001). Domoic acid binds iron and copper: a possible role for the toxin produced by the marine diatom Pseudo-nitzschia. Mar. Chem. 76, 127-134. doi: 10.1016/S0304-4203(01)00053-6

Sellner, K. G., Doucette, G. J., and Kirkpatrick, G. J. (2003). Harmful algal blooms: causes, impacts and detection. J. Ind. Microbiol. Biotech. 30, 383-406. doi: 10.1007/s10295-003-0074-9

Shi, D., Xu, Y., Hopkinson, B. M., and Morel, F. M. M. (2010). Effect of ocean acidification on iron availability to marine phytoplankton. Science 327, 676-679. doi: 10.1126/science.1183517

Sobrinho, B. F., Mocelin de Camargo, L., Sandrini-Neto, L., Kleemann, C. R., da Costa Machado, E., and Mafra, L. L. Jr. (2017). Growth, toxin production and allelopathic effects of Pseudo-nitzschia multiseries under iron-enriched conditions. Mar. Drugs 15, 1-16. doi: 10.3390/md15100331

Sugie, K., Endo, H., Suzuki, K., Nishioka, J., Kiyosawa, H., and Yoshimura, T. (2013). Synergistic effects of pCO2 and iron availability on nutrient consumption ratio of the Bering Sea phytoplankton community. Biogeoscience 10, 6309-6321. doi: 10.5194/bg-10-6309-2013

Sugie, K., and Yoshimura, T. (2013). Effects of pCO2 and iron on the elemental composition and cell geometry of the marine diatom Pseudo-nitzschia pseudodelicatissima. J. Phycol. 49, 475-488. doi: 10.1111/jpy.12054

Tammilehto, A., Nielsen, T. G., Krock, B., Møller, E. F., and Lundholm, N. (2015). Induction of domoic acid production in the toxic diatom Pseudo-nitzschia seriata by calanoid copepods. Aqu. Toxins 159, 52-61. doi: 10.1016/j.aquatox.2014.11.026

Thessen, A. E. (2007). Taxonomy and Ecophysiology of Pseudo-nitzschia in the Chesapeake Bay. (Ph.D. thesis). College Park, MD. University of Maryland.

Tian, D., and Zhang, G. (2019). Toxic effects of domoic acid on Caenorhabditis elegans and the underlying mechanism. Int. J. Biol. 11:v11n3p1. doi: 10.5539/ijb.v1ln3p1

Todd, E. C. D. (1989). "Amnesic shellfish poisoning - a new seafood toxin syndrome," in Toxic Marine Phytoplankton, 4th International Conference Lund, eds E. Graneli, B. Sundström, L. Elder, D. M. Anderson (New York, NY: Elsevier), 504-508.

Trick, C. G., Bill, B. D., Cochlan, W. P., Wells, M. L., Trainer, V. L., and Pickell, L. D. (2010). Iron enrichment stimulates toxic diatom production in highnitrate, low-chlorophyll areas. Proc. Nat. Acad. Sci. U.S.A. 107, 5887-5892. doi: 10.1073/pnas.0910579107

Trimborn, S., Lundholm, N., Thoms, S., Richter, K.-U., Krock, B., Hansen, P. J., et al. (2008). Inorganic carbon acquisition in potentially toxic and non-toxic diatoms: the effect of $\mathrm{pH}$-induced changes in seawater carbonate chemistry. Physiol. Plant. 133, 92-105. doi: 10.1111/j.1399-3054.2007.01038.x

Vera-Avila, L., Marin-Perez, D. Y., and Covarrubias-Herrera, R. (2011). Trace level determination of domoic acid in seawater by off-line/on-line solid-phase extraction coupled to HPLC-UV. J. Mex. Chem. Soc. 55, 65-71. Available online at:http://www.scielo.org.mx/scielo.php?script=sci_arttext\&pid=S1870249X2011000200001\&lng=es\&nrm=iso

Wang, L., and Zheng, B. (2008). Toxic effects of fluoranthene and copper on marine diatom Phaeodactylum tricornutum. J. Env. Sci. China 20, 1363-1372. doi: 10.1016/S1001-0742(08)62234-2

Wang, Z., Maucher-Fuquay, J., Fire, S. E., Mikulski, C. M., Haynes, B., Doucette, G. J., et al. (2012). Optimization of solid-phase extraction and 
liquid chromatography-tandem mass spectrometry for the determination of domoic acid in seawater, phytoplankton, and mammalian fluids and tissues. Anal. Chim. A 715, 71-79. doi: 10.1016/j.aca.2011. 12.013

Wells, M. L., Trick, C. G., Cochlan, W. P., Hughes, M. P., and Trainer, V. L. (2005). Domoic acid: the synergy of iron, copper, and the toxicity of diatoms. Limnol. Ocean 50, 1908-1917. doi: 10.4319/lo.2005.50.6.1908

Wingert, C. J. (2017). The Effects of Ocean Acidification On Growth, Photosynthesis, and Domoic Acid Production by the Toxigenic Diatom, Pseudo-Nitzschia Australis. (Ph.D. thesis). San Francisco: San Francisco State University.

Woods, A. (2016). Domoic Acid Production in Pseudo-Nitzschia (Bacillariophyceae) as a General Response to Unbalanced Growth: The Role of Photo-Oxidative Stress. (Ph.D. thesis). Monterey Bay, California State University.

World Meteorological Organization (2020). World Meteorological Day focus on Climate Change and Water. Climate \& Water, Geneva. Available online at: https://public.wmo.int/en/media/press-release/world-meteorological-dayfocus-climate-change-andwater\#:\$ $\$$ sim $\$:$ text $\$=\$$ World $\% 20$ Meteorological \%20Day\%20takes\%20place,establishing\%20the\%20World\%20Meteorological \%20Organization (accessed March 23, 2020).

Wright, J. L. C., and Quilliam, M. A. (1995). "Methods for domoic acid, the amnesic shellfish poisons," in Manual on Harmful Marine Microalgae,
Intergovernmental Oceanographic Commission Manuals and Guides No 31, eds G. M. Hallegraeff, D. M. Anderson, A. D. Cembella (Paris: UNESCO), 13-133.

Xu, N., Tang, Y. Z., Qin, J., Duan, S., and Gobler, C. J. (2015). Ability of the marine diatoms Pseudo-nitzschia multiseries and P. pungens to inhibit the growth of co-occurring phytoplankton via allelopathy. Aq. Micro. Ecol. 74, 29-41. doi: 10.3354/ame01724

Zabaglo, K., Chrapusta, E., Bober, B., Kaminski, A., Adamski, M., and Bialczyk, J. (2016). Environmental roles and biological activity of domoic acid: a review. Algal Res. 13, 94-101. doi: 10.1016/j.algal.2015.11.020

Conflict of Interest: The authors declare that the research was conducted in the absence of any commercial or financial relationships that could be construed as a potential conflict of interest.

Copyright (c) 2020 Cabrera, González and Puntarulo. This is an open-access article distributed under the terms of the Creative Commons Attribution License (CC BY). The use, distribution or reproduction in other forums is permitted, provided the original author(s) and the copyright owner(s) are credited and that the original publication in this journal is cited, in accordance with accepted academic practice. No use, distribution or reproduction is permitted which does not comply with these terms. 